\title{
Exclusion and Articulation: Transgender Counter-Public in the Indian Public Sphere
}

Parul Priya $^{+*}$ and Dr. Anurag Kumar ${ }^{\dagger}$

\section{Abstract}

The study attempts to locate transgender counter-public as an alternate public sphere in India. It argues that transgender counter-public is necessitated owing to the exclusionary practices of the Indian public sphere as well as the successive counter-public spheres. The study, further claims that transgender counter-public is constructed by critiquing the marginalisation of transgender people through exclusionary practices, and articulation of concerns linked to transgender people. Public discourse analysis of both discursive arenas-print: newspaper articles, journal articles, autobiographies, biographies, memoir, and others, and non-discursive arenas-activism, pride parade, protests and alike have been adopted as methodology. The study concludes that transgender counter-public achieves the dissemination of their concerns to the wider public that exclusion and discrimination of transgender people are a denial of social justice in the democratic social structure.

Keywords: Transgender Counter-public; Indian Public Sphere; Marginalisation; Exclusion; Articulation

\footnotetext{
+ Shri Mata Vaishno Devi University

${ }^{*}$ Corresponding Author, Email: bakshiparul1@gmail.com

(C) 2020 Priya \& Kumar. This is an Open Access article distributed under the terms of the Creative Commons Attribution License (http://creativecommons.org/licenses/by/2.0), which permits unrestricted use, distribution, and reproduction in any medium, provided the original work is properly cited.
} 


\section{Introduction}

The idea of the public sphere emerged with the publication The Structural Transformation of the Public Sphere by the German philosopher Jürgen Habermas. The notion of the public sphere conceptualises the creation of a Bourgeoisie space, where "private people come together as a public...against the public authorities themselves, to engage them in a debate over the general rules governing relations in the basically privati[s]ed but publicly relevant sphere of commodity exchange and social labo[u]r" (Habermas, 1989, p.27). Such "convivial discussion and rational-critical public debate" (Habermas, 1989, p.28) used to take place in the "coffee houses, the salons, and the...table societies" (Habermas, 1989, p.30). It served the dual purpose, at one level, it deputed an interactional discourse where the "power of the better argument won out" (Charles \& Rohwer, 2015, p.2), however, at another level, it strengthened the matrix of democratic society where "equality was key to the public sphere" and "the principle of universal access was crucial" (2015). It aimed to yield the conscious perspective by indulging in "critical discussion and deliberations with the idea of delivering common good" (Singh, 2009, p.270). However, Habermas' idealistic Bourgeoisie public sphere was critiqued for its exclusionary practices and for failing "to examine other, nonliberal, nonbourgeois, competing public spheres" (Loehwing \& Motter, 2009, p.220) which resulted in the formation of counter-publics.

Though Habermas' public sphere created a kind of common social good in Europe due to "shared language and the same normative, objective and subjective worlds of its participants" (Bhargava \& Reifield, 2005), its borrowing and application to the Indian public sphere, "has failed to generate social good, but rather furthers marginali[s]ation and exclusion" of few groups (Singh, 2009, p.271). Unlike the European public sphere, which is unilateral in nature, the Indian public sphere witnesses the fragments due to the plurality of culture, religion, and caste. ${ }^{1}$ In fact, India has "more than 10,000 distinct communities (Castes and Tribes), several religious sects and sub-groups, over a hundred major linguistic categories...in the name of diversity" (Singh, 1996). However, despite many differences, the Indian public sphere shares the exclusionary practices with the Habermasian model of the public sphere by ostracising tribals, Dalits, women, sexual minorities and people with disabilities (Saksena 2014).

In India, there appears to be no space for sexual minorities like for transgender people. ${ }^{2}$ The term 'transgender' refers to those "individuals whose sexual assignment at birth does not correspond with their current gender identity" (Melendez \& Pinto, 2007, p.233). Transgender may also be stated as an "umbrella term that refers to people whose gender identity differs from the sex they were assigned at birth" (Davidson, 2016, p.2). Thus, the term transgender refers to all the people whose gender identity does not conform to the norms of heterosexuality. In India, transgender people are usually and mostly referred to as hijras. ${ }^{3}$ Transgender people's alternate gender identity acts as the very basis of their subaltern existence and exclusion from public and counter-public spheres. Gupta states that " $\mathrm{t}$ ] he transgender community is among the most marginali[s]ed in India, with no access to education and subsequently jobs mostly nonexistent" (2018, para.2). Also, in India, "heteronormativity unceasingly prevails

\footnotetext{
${ }^{1}$ Dalits also known as Untouchables are the people who are excluded from the India's four-fold caste hierarchy, which includes "Brahmin, thepriest ;Kshatriya, nobility and warriors; Vaisya, farmers and traders and Shudra, teneant farmers and servants" (Szczepanski, 2020, para. 2).

${ }^{2}$ According to GLAAD, the term transgender could be used as an adjective however not as a noun. In spite of using the term 'transgenders' or 'a transgender', it is more preferable to use the term 'transgender people' or 'a transgender person' ("Glossary of Terms- Transgender," n.d., para.21). Throughout this paper, we refer to call 'trans', transgenders, as transgender people.

${ }^{3}$ The term "hijra' refers to those who are "neither men nor women" or men who have adopted and exhibited femininity or feminine mannerisms. Hijras hold religious importance in Indian society (“Hijra," 2020, para.1).
} 
for the sole purpose of oppressing homosexuals as a whole" (Sharma \& Sundar, 2016, para.11). The imposition of a majoritarian heteronormative worldview as the only acceptable position adds to the marginalisation of transgender people in particular and people with queer gender identity in general. The key aim of this research is to examine and suggest for a transgender counter-public realm in the Indian public sphere. The study begins with a brief description of the methodology entailed. Following the discussion on methodology, it tries to conceptualise the exclusion of transgender people from the Indian public sphere followed by their exclusion from successive counterpublic spheres (Figure 1). Alongside, it also discusses the issues of consciousness and articulation, and discursive and non-discursive arenas linked to transgender in India. In this way, it tries to discuss the creation of counter-public by way of consciousness ${ }^{4}$ and articulation and categorises articulation as discursive ${ }^{5}$ and nondiscursive 6 arenas and explores how these arenas help transgender people to exhibit their routine struggle and predicament to the society at large.

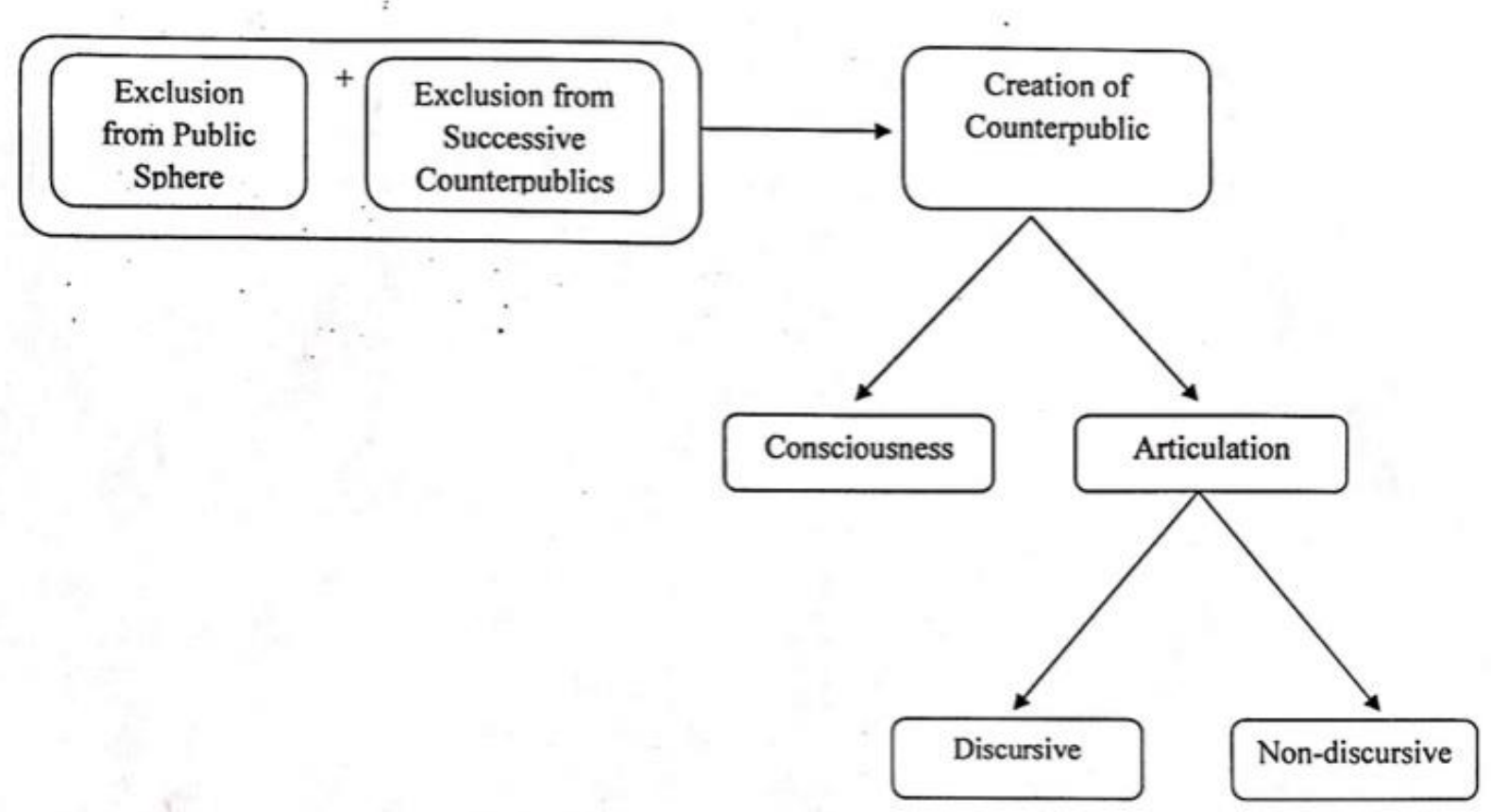

Figure 1: Figurative Representation of Transgender People's Counterpublic

\section{Source: Created by the Authors}

\section{Methodology}

The study uses the Habermasian account of the Bourgeoisie public sphere as a forum to critique and to explore the exclusion of transgender

\footnotetext{
${ }^{4}$ In the paper, the term consciousness signifies awareness. Transgender people's consciousness implies their awareness towards exclusionary practices (Cherry, 2020, para.1).

${ }^{5}$ Discursive arena is what Joanna Brooks termed as Print Counter-public in which through writing one creates a counter-public. It is an arena which "black authors employed to access the print public sphere" and for
}

people from the public sphere and successive counter-public spheres in India. The study assimilates the works of Nancy Fraser, Kanika Batra, and John Landes who gave pushback to Habermas' idea of the public sphere for

creating counter-public by writing poems and manumission (Brooks, 2005, p.68)

${ }^{6} \mathrm{~A}$ Non-discursive arena is the one that involves action. It could be through protests, movements, activism and alike. In other words, non-discursive arena deals with 'doing' rather than 'saying' through the "repeated enactment of bodily performance" (Budden \& Sofaer, 2009, p.204). 
constituting significant exclusions, however, themselves failed to include all of them. It also imbibes the works of critics like Rajeev Bhargava and Shashi Ratnaker Singh for evaluating the Indian public sphere. The study further analyses the Indian public sphere to reflect and affirm the notion of heteronormativity with the help of public discourse analysis through social and literary texts which are complementary to each other. Social texts are adopted based on random selection comprising research articles, interviews, journals, videos and alike which on the one hand show the marginalisation and exclusion of transgender people whereas reflect the articulation and trans counter-public on the other hand. However, literary texts include autobiographies, biographies, and memoir which are construed as an authentic record of the lives of transgender people. Further, the study emphasises on gender more than sexuality. In doing so, the study is an attempt to create critical literacy regarding transgender people while address the transgender concerns in India, amidst the global gender inequalities.

\section{Exclusion from the Indian Public Sphere}

The public sphere excludes transgender people due to their queer gender identity and its belief in the stereotypical ideology of heterosexuality. The institutionalisation of heterosexuality is so deeply "constructed and reconstructed, enacted and re-enacted," (Jackson, 1999, p.5) that sexual minorities have to bear the brunt of collective ostracism, deprivation, and suffering. Sanjana, a transgender woman from New Delhi, accepts that she is bereft of any other option but to beg (Vohra, 2016, para.13). Also, Bandyopadhyay, a transgender college principal is forced to resign due to non-acceptance and backlash from the mainstream ("India's first transgender college principal resigns," 2016, para.1). It is also quite evident in the case of a transgender person from Kerala whose father was asked not to bring her to the church (Augustine, 2016, para.16) and Mithi Sahoo, whose friend was assaulted by a medical worker (Human Rights Law Network, 2015, p.25). Unlike the exclusion of Disabled, Dalits or any other person from the marginalised sections transgender people "often face rejection from their families" ("Transgender and their lives," 2015, para.9).

Transgender people are also discriminated and bullied in educational institutions worldwide, "that can involve name-calling, threats of violence, sexual innuendos or sexual harassment, and even physical assault" (Gay Straight Alliance Network, Transgender Law Center \& National Center for Lesbian Rights, 2010, p.1).In India, transgender students often are "unable to continue their education due to discrimination and humiliation from peers" (Gupta, 2018, para.8) which results in a lesser number of enrolments in educational institutions. Indian Census 2011 "reveals that...just 46 percent transgenders are literate, compared to 74 percent literacy in the general population" (Rajkumar, 2016, p.17).

Transgender people's life narratives also express their exclusion as Revathi, a trans woman narrates, "when I went to buy groceries and vegetable in the vegetable market, people sometimes threw rotten tomatoes at me. They hit me on my back, or even aimed for my head" (Revathi, 2010, p.193). This shows the social unacceptability of transgender people. It further depicts gender ideology and social and political notions regarding gender non-conformers and homosexuals as those who fail to fit under stereotypical standard cultural norms are subjected to an extremist backlash. Bandyopadhyay and Pandey's question summarises this:

How many times have you stopped at a traffic signal and turned your face away from a hijra who stood outside your car window asking for money? Wasn't it worse than what you normally feel when a beggar woman with a child does the same? Why? (Bandyopadhyay and Pandey, 2017, para.1).

Bandyopadhyay and Pandey (2017) unravels that society sympathises with the beggar woman with a child as she conforms to heteronormativity, unlike transgender people who do not follow the socio-sexual norms of society. Moreover, Vidya avers that "transgenders are the Dalits of Dalits, the most 
oppressed women among women-they enjoy no equality, no freedom, no fraternity. They continue to lead a wretched life, devoid of pride and dignity" (Vidya, 2013, p.136).

Transgender people's exclusion from the mainstream also emanates from the denial of basic amenities like sanitation facilities. Revathi narrates, "I... decided to go to the women's toilet there. But the man who stood there dismissed me as a pottai ${ }^{7}$... When I tried to get into the men's toilet section, I was shooed away from there as well" (Revathi, 2010, p.53,54). The deliberation highlights the complex situation of transgender people where they feel like using female bathroom aligning with their gender identity, however, owing to their trans identity, they are not welcomed in either of the public places. As evident, the toilet facility has been provided by the mainstream both to males and females, unfortunately not to transgender people.

In India "[t]he essential problem is that law recogni[s]es gender identity purely on the basis of the biological definition of the sex they are born in" (Sagar, 2018, p.11). In fact "the nonrecognition of their gender identity violates
Articles $14^{8}$ and $21^{9}$ of the Constitution of India" ("National Legal Services Authority v. Union of India and others," 2014, p.2). They are deprived of the social and cultural participation, which dispossess them from the Constitutional guarantee of equality. Johar petition ${ }^{10}$ of 2018 argues that along with the violation of Articles14, $15^{11}, 19^{12}$ and 21 , section 377 also violates Article $16^{13}$ of the Indian Constitution. His petition "further expanded the scope of Article 21 by including privacy, selfdetermination and individual autonomy within its ambit" (Borah, 2018, p.17) and validated the long struggle endured by LGBTQ community by encompassing "several personal narratives of direct and indirect discrimination" (p.18). More so, India is not the only country where same-sex relations are criminalised. As per the International Lesbian, Gay, Bisexual, Trans and Intersex Association, [s]ame-sex relations are criminalised in 72 countries and territories and punishable by death in eight with "dozens more in which homosexual act can result in a prison sentence" (Duncan, 2017). Table 1 uncovers the transgender people's exclusion from the legal system in India.

\footnotetext{
${ }^{7}$ The term pottai refers to sari-clad feminine men (Revathi, 2010, p. 24).

${ }^{8}$ Article 14 of the Constitution of India reads that the "[s]tate shall not deny to any person equality before the law or the equal protection of the laws within the territory of India" ("Article 14 in The Constitution Of India 1949," n.d., para. 1).

${ }^{9}$ Article 21 of the Constitution of India states that "[n]o person shall be deprived of his life or personal liberty except according to procedure established by law" (“Article 21 in The Constitution Of India 1949," n.d., para. $1)$.

${ }^{10}$ The Johar judgment has had an impact on multiple levels. An adjustment in the outlook could be seen in pride parades attended by the LGBTQ community without hiding their faces behind masks. Besides, there was an openness regarding LGBT issues. One could witness more

and more people coming out of their closets and accepting their identities (Narrain, 2019).

Other than that, the community has found a place in mainstream politics and public entertainment. An increase in the visibility of the LBGTQ people is one of the main reasons why acceptance has grown so steadily ("One year after Section 377 verdict," 2019, para.1).

11 Artcle 15 of the Constitution of India probihits discrimination on "grounds of religion, race, caste, sex or place of birth" ("Article 15 in The Constitution Of India 1949," n.d., para. 1).

${ }^{12}$ Article 19 states "[p]rotection of certain rights regarding freedom of speech etc" ("Article 19 in The Constitution Of India 1949," n.d., para. 1).

${ }^{13}$ Article 16 reads "[e]quality of opportunity in matters of public employment" ("Article 16 in The Constitution Of India 1949," n.d., para. 1).
} 


\begin{tabular}{|l|l|l|}
\hline S. No. & \multicolumn{1}{|c|}{ Section } & \multicolumn{1}{c|}{ Description } \\
\hline 1. & Hindu Marriage Code & $\begin{array}{l}\text { Transgender people are excluded from Hindu } \\
\text { marriage code ("Hindu Marriage Act 1955," 2018) }\end{array}$ \\
\hline 2. & Criminal Tribes Act 1871 & $\begin{array}{l}\text { Accuses transender people to be involved in } \\
\text { castrating and kidnappith children ("Human Rights } \\
\text { Violations against the Transgender Community," } \\
\text { 2003) }\end{array}$ \\
\hline 3. & & $\begin{array}{l}\text { Does not identify transgender people's' rape as } \\
\text { serious issue (Dwivedi, 2014, p.6) }\end{array}$ \\
\hline
\end{tabular}

Table 1: Transgender People's exclusion from Indian Legal system

\section{Source: Created by the Authors}

The Supreme Court of India has decriminalised Section 377 of Indian Penal Code and legalised homosexuality "consensual... sex between adults" ("Section 377 verdict: Supreme Court legalised homosexuality," 2018, p.1); however, the verdict is not being translated into social practices. Kothari, a senior advocate of the Supreme Court states that the real inclusivity lies beyond legal acceptance (Narrain, 2019). The averment justifies what Singh and Kumar approve of the execution of public sphere rhetoric on the one hand, and deferring of counter-public discourse to be implemented in practice on the other hand (Singh and Kumar, 2019). In fact "[t]he judgment has limitedly helped transgender people and those targeted by the police, but familial and social acceptance is still a pipe dream for many" (Narrain, 2019). National Legal Services Authority v. Union of India and others pronounce:

Social justice does not mean equality before law in papers but to translate the spirit of the Constitution, enshrined in the Preamble, the Fundamental Rights and the Directive Principles of State Policy into action, whose arms are long enough to bring within its reach and embrace this right of recognition to the TGs which legitimately belongs to them (2014, p.106,107).

This observation could be witnessed in various incidents. For example, on 9 September 2018, Uma, a transgender woman from Delhi "and her friend, also a transgender woman, were physically assaulted by a policeman after he stopped them from begging" (Manjunath, 2018, para.5). Another trans woman divulges that "legalising homosexuality will not end the discrimination that India's queer community faces" (Dasgupta, 2018, para.6). Bhan, an activist proclaims that "[t]he law cannot solve the question of prejudice in all of these spaces" (Dasgupta, 2018, para.43).

\section{Exclusion from Counter-Public Spheres}

Along with the public sphere, transgender people are also excluded from successive counter-discourses. Counter-publics, "emerged as a critical term to signify that some publics develop not simply as one among a constellation of discursive entities, but as explicitly articulated alternatives to wider publics that exclude the interests of potential participants" (Asen, 2000, p.424). In other words, counter-publics are formed as a response to the dominant form of exclusionary deliberation of the public sphere. Consequently, transgender people, being the excluded group, form competing counter-public agents against the conceptualisation of the public sphere and successive counter-publics, critiquing their non-inclusion. This calls into question the reason for their non-existence, especially in successive counter-publics. The successive counter-publics follow social inequalities in general and gender discrimination in particular. The locus of 'counter' in counterpublics varies as Fraser critiques Habermasian Bourgeoisie public sphere for significant exclusions. She recapitulated the public sphere and included the exclusions on the basis of gender. Her alternate publics constitute 
"subordinated social groups-women, workers, peoples of colo[u]r, and gays and lesbian" (Fraser,1990, p.67) which she calls as 'subaltern counter-publics' (Fraser, 1990, p.67). The centre of Fraser's research is mainly women presenting a gender-based counter-public. Though Fraser mentions gays and lesbians, there is no deliberation beyond a mention on the subject; rather she focuses on 'feminist subaltern counter-public'. Thus, Fraser's rumination has been restricted to the traditional category of sexism, of being male and female.

Similarly, Batra mainly emphasises the physical and sexual violence faced by women in and around Delhi and makes use of the term 'locationality' along with gender (2016). Though Batra propounds on gender, however, her gender sustains with the location; she calls it as 'locational counter-public'. Moreover, in her disquisition, Batra places "women's sexuality at the forefront of national concerns through a rights discourse" (2016, p.845), nevertheless, she fails to understand gender beyond heteronormativity. Though both Fraser and Batra conferred about gender, they could not move ahead of traditional heteronormative gender categories to define publics and counterpublics. Similarly, Landes (as cited in Fraser 1990) also asserts about gender:

The ethos of the new republican public sphere in France was constructed in deliberate opposition to that of a more woman-friendly salon culture that the republicans stigmatised as "artificial," "effeminate," and "aristocratic." Consequently, a new, austere style of public speech and behavior[u]r was promoted, a style deemed "rational," "virtuous," and "manly." (as cited in Fraser, 1990, p.59).

The above-propounded deliberation touches the construct of gender and disseminates the scenario where the female public sphere is opposed and even substituted with the male sphere. However, Landes'(as cited in Fraser 1990) elucidation of 'gender' is also dichotomous wavering between masculinity and femininity, leaving no avenue for third gender and gender non-conformers.

Therefore, none of the critics indicated above goes beyond the limits of perpetuated gender divisions. Further, none of them has talked about transgender people as part of their counterpublic. Much like public sphere enormities such as discrimination in public employment, education, violence, homelessness and alike, counter-public spheres also practise exclusionary practices against the transgender people; thus, they necessitate a kind of counterpublic which is known as transgender or trans counter-public.

\section{Consciousness and Articulation}

From the instances of exclusion stated above, transgender people's writings publicise that they are conscious of their exclusion and marginality. They articulate their exclusion either through a discursive or non-discursive domain, which further helps them in formulating counterpublic. Any counter-public exists by way of two modules: Consciousness and Articulation. Primarily being consciousness, it attains the first position in the creation of counter-public. As argued by Warner "a counter-public maintains at some level, conscious or not, an awareness of its subordinate status. The cultural horizon against which it marks itself off is not just a general or wider public, but a dominant one" (2002, p.119). In the case of transgender people conspicuously, not only they are conscious of their queer position in society, but also they are willing to articulate their elimination from the wider public sphere. The stance of consciousness towards transgender people's exclusion is quite evident in Revathi's autobiography, where she expounds:

Since people are not aware of our existence, they think ill of us. It is our duty to dispel such ignorance. Just as how [D]alits have come to oppose the violence inflicted on them, why cannot we hijras get together and fight for our rights...Aren't we human too, born of mothers, as others are? We have not descended from the sky, have we? We 
have rights, just like others (Revathi, 2010, p.247).

The contemplation exhibits the impediment of transgender people where their exclusion from the Indian public sphere becomes one of the rationales for their consciousness. A similar concern is shared by Bandyopadhyay, "[t]o all those people who humiliated me and called me subhuman, pushing me to the brink of my life. It is because of them that I discovered my strength and fought back my way to life" (Bandyopadhyay, 2017, para.1). The idea of consciousness and articulation manifested by Revathi and Bandyopadhyay reveals one of the ways they identify their exclusion and protest against the socio-cultural norms of the society which as a whole creates collective consciousness and willingness for articulation amongst transgender people, which further assists them in claiming their rights and attaining emancipation.

As discussed above, the articulation prevails through discursive and non-discursive arenas. Discursive articulation includes articulation through print, movies, interviews, etc. However, non-discursive arenas comprise activism, pride parades, LGBT protests which help in articulating transgender people's marginalisation and establishing counter-public.

\section{Discursive Arenas}

The articulation of transgender people's spurning and marginalisation is achieved through their counter-narrative via discursive and non-discursive arenas. How discursive arenas like print help in forestalling transgender people's atrocities to the forefront is illustrated by Revathi while talking to Mary in one of her interviews:

During my initial days of work with Sangama ${ }^{14} .$. .I decided to do my own research and interviewed around 50 members of the community... I was also often asked to talk about myself at various forums and would be given [a]

\footnotetext{
${ }^{14}$ Sangama is an NGO for sexual minorities: lesbians, gays, transgender people and others who are discriminated due to their sexuality and sexual preferences. Sangama works
}

very short time. My experiences were so vast I felt I was not doing justice in that five-minute slot. That's when I thought I should come forward with my story as well. What better way than to write an autobiography? (Mary, 2014, para.5,6).

Revathi (while narrating to Mary) highlights that writing has helped her to articulate about herself especially through her autobiography. Her consciousness and then the articulation of marginalised position paved a way for an alternate public sphere. Moreover, articulation undoubtedly gives recognition if not an acceptance which is evident in an interview with former U.S. President Barack Obama, where a question is raised by Akkai Padmashali, a transgender social activist, regarding the atrocities that sexual minorities face (especially the transgender people) who are voiceless as they are criminalised under section 377 . In response to the question raised by Padmashali, Obama evinces minorities to raise their voice as awareness and articulation are the two main attributes required (NDTV, 2017).

Transgender people, using discursive arenas articulate their atrocities, stand up for themselves and create their own sphere. Moreover, queer gender concerns, in the present, are articulated through numerous journals, clearly constructing a platform for transgender people's articulation like International Journal of Transgenderism, Transgender Studies Quarterly, GLQ: A Journal of Gay \& Lesbian Studies and many others. The same can be viewed in magazines as well, like Pink Pages, Daily Xtra, Lavender and others.

A transgender student, Anamika from IIT Kharagpur talks about her life's encounter and experience in a campus newsletter. Anamika's proclamation about her gender identity has been described by her "as the beginning of an awareness drive" (Basu, 2015, para.4). She promulgates her torment arising out of gender non-conformity as "I started to hit myself on the head; it was the only place where bruises could

for the betterment and upliftment of LGBTQ ("Sangama," para.1). 
be easily hidden. I became totally unforgiving towards myself. My self-esteem was in shreds and I became a completely under-confident person" (Basu, 2015, para. 8). This enunciates the torture that transgender people go through before articulating; however, the decision of articulation has been considered by Anamika as the best decision ever made by her (Basu, 2015).

Similarly, Aher, a transgender person, discloses the truth about her and the society. Through TEDxUSICT, she speaks against the collective set of beliefs of the Indian public sphere. She discloses the common perceptions of people regarding the community, which are fear, pity, mystery and shame due to their different gender identity. She raises the point of familial acceptance as for a longer period she has not been allowed to be a part of any of her family functions. Moreover, she also talks about her experience of being rejected by seventeen hotels in a row, in Kerala, due to her gender nonconformity. Irrespective of having money in her bag, she is not allowed to enter into a shop for buying a saree, she expounds the dialogue between her and the shopkeeper:

I had 10,000 cash in my kitty and I wanted to buy a saree, I wanted to enter into a shop and shop said that

no, you cannot enter into a shop,

Why?

Because you are a hijra, you are a hijra person.

I have money. Can you have a look at it? I have 10000 rupees...

No, you cannot buy a saree because we reserve a right to admission (Aher, 2015, 6:26-6:51).

Instances like that expose the discriminatory grounds on which transgender people live. Their entry into a public place is part of their routine struggle. The abomination, prejudice and disparage, that Aher faced in her life have indeed, made her conscious of her position and forced her to articulate the wrongs done to her. Her articulation is a part of transgender people's counter-discourse asking for an acknowledgement (Aher, 2015).

\section{Non-discursive Arenas}

The non-discursive arena includes activism, movement, parades and alike to acknowledge transgender people's demands, grievances, and criticism. One of the notable protests took place in New Delhi at Sansad Marg where several LGBTQ activists protested against the Transgender Persons (Protection of Rights) Bill 2016 which failed to cater to their needs of acceptance and legal recognition. It criminalised begging, which is one of their major sources of income (Hasan, 2017). A similar kind of protest took place in Mohali where transgender people blocked the traffic and climbed the car to show their anger towards police for "harassing them after a video showing naked transgenders chasing people for money became viral" (Sehgal, 2018, para.5). Such kind of protests helps in negotiating for them a social position in the Indian public sphere.

Moreover, articulation through non-discursive arenas addresses "the problemati[s]ation of social norms, the invention of alternatives to those norms, and the creative practice of these newly invented possibilities" (Dave, 2012, p. 3). Further, an example of LGBTQ parade was quite apparent in Bhopal where the members of the LGBTQ community came on roads and demanded Madhya Pradesh government to establish Transgender and Sexual Minorities Welfare Board ("LGBTQ community parade with pride in first for Bhopal," 2017). Such kind of rallies and parades are one of the ways to negotiate an alternative public sphere for transgender people where they may practice their needs and requirements. Another significant queer pride parade took place in Delhi, where "the crowd sang, danced and celebrated as people from all walks of life, identifying with different sexual orientations and genders got together" (Kohli, 2017, para. 2) to appreciate their collective struggle. One of the Chennai based activists in the parade illustrates the impact of such parades: "This is like coming out for us. We are expressing our right to live 
with dignity. The attitude of the society towards us has to change" (Kohli, 2017, para.9).

Articulation through discursive arenas like print and life narratives articulate the essence of exclusion from the Indian public sphere and create an alternate public sphere based on needs, interests and well being of transgender people. Moreover, the non-discursive domain like activism, movement, parades and alike, also play a vital role in constructing transgender counter-discourse.

\section{Conclusion}

The study foregrounds and imparts the rationale behind transgender people's counter-public, which is their exclusion from the wider public sphere that does not give any consideration to their existence. Transgender people, by constructing their alternate public sphere, which is termed in this study as transgender counterpublic, not only critique the Indian public sphere as well as successive counter-publics but also negotiate an alternate public sphere. Furthermore, transgender people's consciousness about their marginal position and queer gender identity, along with the articulation of the same, paves the way for their counter-public which provides them at least recognition if not acceptance.

Further, the study reflects the construction of their counter-public through discursive and nondiscursive arenas. Discursive realms such as print, interviews, videos, and other sources help in forestalling transgender people's atrocities to the forefront. This is quite evident in transgender people's autobiographies, biographies, memoirs and other mediums of print and media which provide real, dependable and authentic realities of transgender communities. Moreover, non-discursive domains such as protests, parades, rallies and alike not only help them in articulating their exclusion and marginalisation from the Indian public sphere but also make way for publicising their resistance towards the heteronormative norms of the public sphere, which further acts as a driving force for creating counter-public. The mainstream Indian heteronormative agencies exclude transgender people from practising legal and human rights. Moreover, the Indian heteronormative agencies also practice discriminations against the transgender people, which results in the refusal of equity and integrity in a democratic social structure. Therefore, through their counter-public, transgender people are trying to get their gender identity recognised if not accepted in the Indian public sphere.

\section{References}

Aher, A. (2015, 28 July). Situation of transgenders in India. Youtube.com. Retrieved on 16 February 2017 from, https://www.youtube.com/watch?v=Uup8zyQpcQ

Article 14 in The Constitution Of India 1949. (n.d.). Retrieved on 16 February 2017 from, https://indiankanoon.org/doc/367586/

Article 15 in The Constitution Of India 1949. (n.d.). Retrieved on 16 February 2017 from, https://indiankanoon.org/doc/609295/

Article 16 in The Constitution Of India 1949. (n.d.). Retrieved on 16 February 2017 from, https://indiankanoon.org/doc/211089/

Article 19 in The Constitution Of India 1949. (n.d.). Retrieved on 16 February 2017 from, https://indiankanoon.org/doc/1218090/

Article 21 in The Constitution Of India 1949. (n.d.). Retrieved on 16 February 2017 from, https://indiankanoon.org/doc/1199182/

Asen, R. (2000, 1 November). Seeking the "Counter" in Counter-publics. Communication Theory, 10(4), 424-446, Retrieved on 29 August 2018 from, https://doi.org/10.1111/j.14682885.2000.tb00201.x

Augustine, A. (2016, 9 January). Third Gender and the Crisis of Citizenship: Migration from Kerala to Tamil Nadu. Economic \& Political Weekly, 51(2), 1-6. Retrieved on 19 March 2018 from,

https://www.epw.in/journal/2016/2/reportsstates/third-gender-and-crisiscitizenship.html?0=ip_login_no_cache\%3Dcb76 6868a0a579473f3a1c283c59c748 
Bandyopadhyay, B. \& Pandey, J.M. (2017). A Gift of Goddess Laxmi. India: Penguin Random House.

Basu, M. (2015, 24 May). Transgender student hopes her coming-out story sets an example.

The Indian Express. Retrieved on 19 June 2018 from,

http://indianexpress.com/article/lifestyle/trans gender-student-hopes-her-coming-out-storysets-an-example/

Batra, K. (2016). Creating a locational counterpublic: Manushi and the articulation of human rights and sexuality from Delhi, India. Signs: Journal of Women in Culture and Society, 41(4), 845-867. Retrieved on 9 May 2017 from, https://doi.org/10.1086/685118

Bhargava, R. \& Reifeld, H. (2005, April). Civil Society, Public Sphere and Citizenship: Dialogues and Perceptions. New Delhi: Sage Publications.

Borah, P.K. (2018, 22 November). Engaging with the law: Decriminalisation of homosexuality and the Johar Judgement, 2018. Space and Culture, India, 6(3), 5-22. Retrieved on 6 September 2019 from, doi.org/10.20896/saci.v6i3.400

Brooks, J. (2005, January). The Early American Public Sphere and the Emergence of a Black Print Counter-public. The William and Mary Quarterly, 62(1), 67-92. doi: 10.2307/3491622

Budden, S. \& Sofaer, J. (2009). Non-Discursive knowledge and the construction of identity: Potters, Potting and Performance at the Bronze Age Tell of Szazhalombatta, Hungary. Cambridge Archaeological Journal, 19(2), 203220. Retrieved on 23 February 2020 from, doi:10.1017/s0959774309000274

Charles, G.U., \& Rohwer, L.F. (2015). Habermas, the public sphere, and the creation of a racial counter-public. Michigan Journal of Race and Law, 21(1), 1-21. Retrieved on 15 March 2018 from, https://repository.law.umich.edu/cgi/viewcont ent.cgi article $=1048 \&$ context $=\mathrm{mjrl}$

Cherry, K. (2020, 24 February). Consciousness is the Psychology of Awareness. Verywellmind. Retrieved on 26 February 2020 from, https://www.verywellmind.com/what-isconsciousness-2795922

Dasgupta, P. (2018, 6 September). Section 377 Verdict: Supreme Court Decriminalises Gay Sex, Heeds Indian LGBT Community's Long Struggle. Huffpost. Retrieved on 21 October 2018 from, https://www.huffingtonpost.in/2018/09/06/sec tion-377-india-s-queer-community-has-foughtlong-enough-it-s-the-sc-s-turnnow_a_23518650/

Dave, N. N. (2012). Queer Activism in India: A Story in the Anthropology of Ethics. U.S.: Duke University Press.

Davidson, S. \& Halsall, J. (2016). Gender inequality: Non-binary Transgender people in the Workplace. Cogent Social Sciences, 2(1), 112. doi: $10.1080 / 23311886.2016 .1236511$

Duncan, P. (2017, 17 July). Gay relationships are still criminalised in 72 countries, report finds.

The Guardian. Retrieved on 12 September 2019 from,

https://www.theguardian.com/world/2017/jul/

27/gay-relationships-still-criminalisedcountries-report

Dwivedi, A. V. (2014). Rape in the Metropolis: The geography of crime in Delhi. Glocalism: Journal of Culture, Politics and Innovation, 3, 19. doi: 10.12893/gjcpi.2014.3.6

Fraser, N. (1990). Rethinking the Public Sphere: A contribution to the critique of actually existing Democracy. Social Text, No. 25/26:, 5680. doi $10.2307 / 466240$

Gay Straight Alliance Network, Transgender Law Centre, National Center for Lesbian Rights. (2010). Beyond the binary: A tool kit for gender identity activism in Schools. Retrieved on 21 October 2017 from, https://gsanetwork.org/wpcontent/uploads/2019/04/BeyondtheBinaryv2.pdf

Glossary of Terms- Transgender. (n.d.). Retrieved on 16 February 2017 from, https://www.glaad.org/reference/transgender Gupta, S. (2018, 16 July). Indian state takes a step forward for transgender rights, CNN. Retrieved on 11 February 2018 from, 
https://edition.cnn.com/2018/07/16/health/ind ia-kerala-transgender-laws-bill-intl/index.html

Habermas, J. (1989). The structural transformation of the public sphere: an inquiry into a category of bourgeois society. (T. Burger, Trans.). Cambridge: The MIT Press. (Original work published 1962)

Hasan, I. (2017, 17 December). LGBTQ community protests against transgender persons bill. India Today. Retrieved on 16 February 2017 from, https://www.indiatoday.in/india/story/lgbtqcommunity-protests-against-transgenderpersons-bill-1110328-2017-12-17

Hijra. (2020, 20 February). Retrieved on 16 February 2017 from, https://www.encyclopedia.com/philosophyand-religion/islam/islam/hijra

Hindu Marriage Act 1955. (2018, January). Net Lawman. Retrieved on 21 February 2017 from, https://www.netlawman.co.in/ia/hindumarriage-act-1955

Human Rights Violations against the Transgender Community: A PUCL Report (2003, September). Retrieved on 4 April 2017 from, http://pucl.org/sites/default/files/reports/Hum an_Rights_Violations_against_the_Transgender _Community.pdf

India's first transgender college principal resigns. (2016, 29 December). The Times of India. Retrieved on 14 February 2018 from, https://timesofindia.indiatimes.com/india/india s-first-transgender-college-principalresigns/articleshow/56242412.cms

Issues Faced by Transgender persons in Odisha: Fact-Finding Mission to Bhubaneswar and Cuttack. (2015, 20 July). Retrieved on 12 December 2017 from, https://www.hrln.org/hrln/images/stories/pdf/ Transgender-Fact-Finding-Report-HRLN.pdf Jackson, S. (1999). Heterosexuality in Question. Retrieved on 19 September from, http://dx.doi.org/10.4135/9781446217382

Kohli, K. (2017, 12 November). Love Is Love: Delhi Hosts Its Tenth Queer Pride Parade. The Wire. Retrieved on 18 October 2018 from, https://thewire.in/gender/delhi-pride-paradeIgbtq-rights

LGBTQ community parade with pride in first for Bhopal, demand welfare board for

Transgender/Sexual Minorities. (2017, 17 May). Indian Express. Retrieved on 17 July 2018 from, http://www.newindianexpress.com/nation/201 7/may/17/lgbtq-community-parade-with-pridein-first-for-bhopal-demand-welfare-board-fortransgendersexual-m-1605921.html

Loehwing, M. \& Motter, J. (2009). Publics, Counter-publics, and the Promise of Democracy. Philosophy \& Rhetoric, 42(3), 220241. Retrieved on 14 February 2017 from, http://www.jstor.org/stable/25655356

Manjunath, K. (2018, 9 October). Delhi's transgender community face police harassment despite Supreme Court's Section 377 verdict. Scroll. Retrieved on 18 November 2018 from, https://scroll.in/article/894435/delhistransgender-community-face-policeharassment-despite-supreme-courts-section377-verdict

Mary, V. (2014, 3 November). Transcending gender barrier. The Hindu. Retrieved on 29 August 2017 from, http://www.thehindu.com/features/metroplus/ society/transcending-genderbarrier/article6560631.ece

Melendez, R. M. \& Pinto, R. (2007, 24 July). It's Really a Hard Life': Love, Gender and HIV Risk among Male-to-Female Transgender Persons. Culture, Health \& Sexuality, 9(3), 233-245. doi.org/10.1080/13691050601065909

Narrain, A. (2019, 6 September). Section 377 judgment on same sex relations: One year later, has anything changed?. The Hindu. Retrieved on 18 October 2018 from, https://www.thehindu.com/society/section377-judgement-one-yearlater/article29342570.ece

National Legal Services Authority v. Union of India and others, (2014, 15 April). Retrieved on 21 October 2017 from, https://www.lawyerscollective.org/wp- 
content/uploads/2014/04/Transgenderjudgment.pdf

NDTV. (2017, 1 December). I'm a Criminal. Youtube.com. Retrieved on 5 April 2017 from, https://www.youtube.com/watch?v=RHZbeLdV $\mathrm{xnY}$

One year after Sec 377 verdict: Stirrings of change but a long way to go for true inclusitivity. (2019, 6 September). Social Story. Retrived on 15 January 2020 from https://yourstory.com/socialstory/2019/09/sec tion-377-supreme-court-verdict-inclusivity

Rajkumar. (2016). Education of Transgenders in India: Status and Challenges. International Journal of Research in Economics and Social Sciences, 6(11), 15-24. Retrieved on 13 November 2017 from, http://euroasiapub.org/wpcontent/uploads/2016/12/2ESSNov-4296.pdf

Revathi, A. (2010). The Truth About Me. India: Penguin Random House.

Sagar, T. (2018, 26 May). Legal Rights of Transgender under The Indian Law. Pleaders.

Retrieved on 18 June 2018 from, https://blog.ipleaders.in/legal-rightstransgender-indian-law/

Saksena, D. (2014, 8 September). The Problems of Marginalised Groups in India. Academike.

Retrieved on 1 March 2017 from, https://www.lawctopus.com/academike/proble ms-marginalized-groups-india/

Sangama: A Resource Centre on Sexuality. (n.d.). Retrieved on 12 March 2018 from, http://www.sacw.net/SexualityMinorities/sang ama.html

Sczcepanski, K. (2020, 13 February). Who are the Dalits?. ThoughtCo. Retrieved on 24

February 2020 from, https://www.thoughtco.com/history-of-indiascaste-system-195496

Section 377 verdict: Supreme Court legalises homosexuality. (2018, 6 September). Indian Express. Retrieved on 12 August 2018 from, http://www.newindianexpress.com/nation/201 8/sep/06/section-377-verdict-supreme-courtlegalises-homosexuality-1868345.html
Sehgal, M. (2018, 29 May). Transgenders block traffic in Mohali after police questions them in connection with highway loot. India Today. Retrieved on 18 September 2018 from, https://www.indiatoday.in/india/story/transgenders-block-traffic-after-policequestions-them-in-connection-with-highway-lo1245304-2018-05-29

Sharma, P. \& Sundar, V. (2016, 27June). Indian cinema and its misguided portrayal of the LGBT community. The News Minute. Retrieved on 18 February 2018 from,

https://www.thenewsminute.com/article/india n-cinema-and-its-misguided-portrayal-lgbtcommunity- 45508

Singh, K.S. (1996). People of India: Communities, Segments, Synonyms, Surnames and Titles. Delhi: Oxford University Press.

Singh, S. \& Kumar, A. (2019, 31 March). Sexual Violence in Indian Public Sphere: Counter-public Creation and Deferral. Space and Culture, India, 6(5), 8-28. doi.org/10.20896/saci.v6i5.317

Singh, S.R. (2009). People and public sphere in India. Social Change, 39(2), 270-280. https://doi.org/10.1177\%2F0049085709039002 06

Transgender and their lives: All you should know about it. (2015, 14 August). India Today. Retrieved on 21 October 2018 from, https://www.indiatoday.in/education-today/gkcurrent-affairs/story/transgender-and-theirlives-288249-2015-08-14

Vidya (2013). I am Vidya: A Transgender's Journey. New Delhi: Rupa Publications.

Vohra, V. (2016, 18 June). Who'll Give Me Respect?: A Trans Woman On Why We Need To Change, Not Just Our Laws. Youth Ki Awaaz.

Retrieved on 16 March 2018 from, https://www.youthkiawaaz.com/2016/06/inter view-transgender-woman-delhi/

Warner, M. (2002). Publics and Counter-publics. Public Culture, 14(1), 49-90.

doi.org/10.1215/08992363-14-1-49 